\title{
On the double refraction of electrical waves
}

\section{Prof. Auguste Right}

To cite this article: Prof. Auguste Right (1896) On the double refraction of electrical waves, Philosophical Magazine Series 5, 41:249, 152-152, DOI: 10.1080/14786449608620832

To link to this article: http://dx.doi.org/10.1080/14786449608620832

$$
\text { 曲 Published online: } 08 \text { May } 2009 .
$$

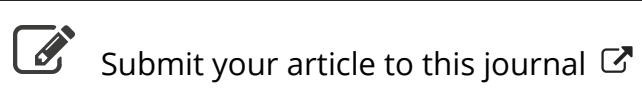

\footnotetext{
Џ Article views: 2
}

Q View related articles $\sqsubset$ 


\section{ON THE DOUBLE REFRACTION OF ELECTRICAL WAVES. BY PROF. AUGUSTE RIGHI.}

In No. 2, 1895, of Wiedemann's Annalen is a memoir by Prof. Mach (Phil. Mag. July 1895), in which are described experiments showing that a plate of pine-wood with faces parallel to the fibres behaves towards electrical radiation just as a double refracting plate towards luminous radiations. This memoir is dated Nov. 1894.

Now on May 27, 1894, I communicated to the R. Accademia di Bologna a long paper in which are described experiments equivalent to those of Prof. Mach, and others of analogous import. In my experiments I not only confirmed the double refraction produced by wood, and the varying absorption of electrical rays according as they are parallel or perpendicular to the fibres, but I also obtained elliptical and circular polarization, using for this latter a wooden plate of such a thickness as to represent a quarter of a wave-lengtb. Thus, like Prof. Mach, I compared the behaviour of wood to that of tuurmaline rather than to that of calcspar or of quartz. One experiment of Prof. Mach's I did not make, namely, that in which it is proved that there is no double refraction if the wooden plate is cut perpendicularly to the fibres. I did not think it necessary to make this experiment, the idea of which did indeed occur to me, because from reasons of symmetry the result seemed a priori evident.

I am satisfied that Prof. Mach did not know of my memoir, or at any rate not when I made iny communication to the Annalen, and $\dot{I}$ am glad that his experiments so completely confirm those I had already published. I may add that, like him, I do not believe in the possibility of producing double refraction of electrical radiations by means of a plate of Iceland spar, for the reasons $I$ have explained in my memoir. In any case $I$ intend soon to resume my researches in these directions, which I have been prevented from doing by other work.-Nuovo Cimento [4] vol.i., April 1895. Communicated by the Author.

NOTE ON FLEMENTARY TEACHING CONCERNING FOCAL LENGTHS. To the Editors of the Philosophical Magazine.

\section{Gentmemen,}

In Dr. Barton's communication, page 59, I see he follows the usual practice with regard to signs. My experience is that students find it simpler and more natural to take the positive sign for real images always, and the negative sign for virtual ones. Similarly, converging instruments are to have their focal length or their "potency" considered positive, and diverging instruments negative, whether they be mirrors or lenses. Does Dr. Barton see objection to this course?

January 3, 1896.

Yours faithfully,

Oliver J. Lodax. 